\title{
Organic Archetypal Patterns in Literature: Origin, Meanings, Interpretations
}

\begin{abstract}
By Natalya Davidko*
The article studies the role and functions of organic archetypal patterns based on the concept of the Tree in literary texts, to which it brings a rich variety of emotive and cultural associations. Being ontologically and epistemologically grounded in the surrounding ecosystems, organic archetypal patterns as a mode of figural modeling run through genres of different epochs and inform their content with a naturalized view of themes, motifs, and situations, which make up the fabric of a work of fiction. Literary figures of this type have their roots in mythological consciousness that at a certain level of human development was instrumental in the categorization of the world and construction of cultural codes as objectivized forms of sensory perception, as pre-discursive human cognitive activity; they have retained till today the symbolic potency of those mythic structures and religious conceptions, often hidden from an uneducated mind. We hypothesize that archetypal patterns forming meaningful connections of language with myth, religion, and art, are used by authors to ensure an integrated understanding of a particular literary piece or its part.
\end{abstract}

Keywords: archetypal pattern, mythological consciousness, ecosystem, cultural code

\section{Introduction}

Very often literary texts contain imagery whose message is difficult to understand for students of literature and which is completely lost on the casual reader; that is imagery in which the archetypal substratum plays a major role. Pierre Bourdieu claims: "A work of art has meaning and interest only for someone who possesses the cultural competence, that is, the code, into which it is encoded" (Bourdieu 1984, p. 2). The key to understanding cultural codes lies in unearthing archetypal latent layers and implications as far and as deep as our knowledge will go. Archetypes, being constructions through which mankind has expressed its experience of cosmos, nature, society, and history to formulate an intelligible view of the world, are an inexhaustible source for imagery which like a wellspring comes from unfathomable depth of human conscience, history and culture to acquire a configuration which meets the needs of a particular fictional situation in the works by past or modern authors. The aim of the article is to analyze organic archetypal patterns based on the concept of the Tree which has been part of our environment since year One and has been perceived as a life giving and life preserving object. The analysis of archetypal patterns can demonstrate how primeval people made sense of our biological environment and transferred environmental factors to cultural codes and how these codes have been made use of in literature and art.

\footnotetext{
*Assistant Professor, Moscow Institute Touro, Russia.
} 


\section{Theoretical Background}

The methodology employed in the current research is Archetypal literary criticism (ALC) complemented by elements borrowed from a new paradigm of linguistic research - Ecolinguistics. ALC postulates that archetypes attach a specific form to literary content involving themes, motifs, characters, and situations and shape a unique figural style which draws on archetypes as patterns for creating literary meaning and special emotional significance. By archetypal patterns we understand "themes having a particular form or pattern" which persist amid variation from age to age (Bodkin 1934, p. 4) and become discernible when embodied in cultural material, whether it is literature or visual arts.

The notion of Archetype (etymologically, a compound of arche + typos signifying 'first impress') appears as a term in Frazer's social anthropology (Fraser 1890), Jungian psychology of the unconscious (Jung 1964), Frye's archetypal literary criticism (Frye 1957), Goethe's metamorphosis of plants (Goethe 2009), modern neuroaesthetics of visual arts (Mukhopadhyay 2014), political sciences and sociology (Larson 2004). Scientists define archetypes from different perspectives: Frazer regarded them as material artifacts; Jung as ideal elements of the "collective unconscious," a universal psyche that the humankind inherits; Frye as a few basic grammatical elements of literary expression, an organizational structural element of literature; Goethe as the primeval form of the plant to be found in the leaf; in sociology, archetypes are equated to cultural models or cultural canon (Neumann 1995).

The ALC theory emerged in the 1930s as a fusion of Jungian psychology and Frazer's social anthropology; it was developed and modified by the Canadian mythologist Northrop Frye with regard to literature in purely literary terms and was first applied to the analysis of literary works by Maud Bodkin in her groundbreaking book of 1934 in which she gives a sweeping picture of archetypal patterns in drama and poetry from Vigil and Dante to Shakespeare to Blake to D.H. Lawrence and V. Woolf in the vein of Jungian psychology; she comes to a conclusion that particular culture patterns through their universal elements relate to the most general conceptions of philosophical interpretations of the world (Bodkin 1934 , p. 315). Due to their universality, archetypes have preserved evocative power and continue to stir emotional response in readers (Bodkin 1934, p. 8). Later, Frye applied his archetypal theory to the analysis of The Bible delineating in its text a few "species of myth" (Frye 1982), which have become the basis for recurrent imagery in literature, an underlying deep structure discernible in various narratives. According to Frye, archetypal patterns establish inter-textual connections of works removed from each other in time owing to conventional, well-established associations that have remained unchanged and recognizable throughout centuries, if not millennia. He cites such archetypes as myths of creation, of fall, of the destruction of the human race, of redemption, crucifixion, etc.

An archetype is a cognitive tool of a specific kind and a unit of mediation in communication based on archetypal references. As articulated by C. Yung, archetypes as deep-seated pre-conceptual, pre-categorial images imprinted in the "collective unconscious" provide instantaneous comprehension without resorting 
to logic. They are archaic patterns that form a "nebulous dynamic substratum" of the surface structure of a literary text and act as a source for figurative thought providing a myriad of images that get specific expression in a culture in the form of archetypal events, figures/characters, and motifs (Jung 1964). It is very close to Locke's definition of signs, "which the mind makes use of for the understanding of things, or conveying its knowledge to others" (Locke 1965, p. 309). In our understanding, archetypal patterns are multidimensional, dynamic, complex entities incorporating multiple associations and significative values. The literary design and specificity of any literary work involve modification and extension of an archetypal pattern depending on the genre, the time of creation, an author's aesthetic preferences, and overarching cultural paradigm.

Since the subject matter of the current research involves natural phenomena, ALC is complemented by methodologies of Ecolinguistics, an interdisciplinary field of linguistics and environmental studies, especially from those sections which concern eco-phenomenology, studies of the relationship between ecosystems and the phenomenal world (Brown and Toadvine 2003) and expose the connections between natural elements and the mechanisms of conceptualizations and meaningmaking in language, which lead to the integration of nature and culture resulting in specific cultural codes among which organic archetypes and archetypal patterns are of primary significance. Conceptualized natural elements belong to the phenomenal world, but have their roots in reality: our task is to investigate how nature is interpreted within a respective culture.

Among various forms of consciousness, mythopoeic perception of the outer world (thinking mythically) characteristic of the minds of peoples at a time when they began constructing the "meaning about the world" played a major role in apprehension of the natural and social environments and understanding of the self. It is a mode of thinking symbolically, which is opposed to the modern way of thinking based on empiricism, scientific reasoning and rationalism. As Cassirer put it, "Before man thinks in terms of logical concepts, he holds his experiences by means of clear, separate, mythical images" (Cassirer 1946, p. 37). Kantian (Kant 1988) distinction between 'phenomena', things as they appear or are represented, from 'noumena', things as they are per se, is not relevant for mythic consciousness as it is characterized by a holistic perception of the world and one's self in it. Mythology is considered to be the "first attempt at a knowledge of the world," (Cassirer 1946, p. 23) and myths are representations of fundamental concepts, which cannot yet be understood in the abstract but should be concretized. The human mind created a mythic reality and inhabited it with gods and supernatural beings as aesthetic configurations of elemental forces and materializations of abstract concepts, e.g., Zeus (thunder and authority), Poseidon (sea) Gaia (Earth), Aphrodite (love and beauty). The legacy of this period is rich imagery reified in multiple patterns which became a truly formative force of literary figurality and offer templates for authors who look for novel aesthetic ways to express concepts, characters, or events. 


\section{Material}

The research proposes to explore the conception and evolution of archetypal patterns within the framework of human - nature relationships. Literature is the milieu in which the processes of meaning-making are made explicit, so we handled the selection of research material very seriously and included literary pieces in which archetypal patterns perform various functions and are indispensible for comprehension. The material under consideration covers a vast range of heterogeneous poetic and prosaic pieces of renown authors: Poetic Edda believed to be reaching into the Viking Age; Euripides, a classical tragedian of $5^{\text {th }}$ century BC Athens; mythological writings by Ovid, a Roman poet of the $1^{\text {st }}$ century BC; Guillaume de Deguileville (1295-1358), a French Cistercian and writer, the author of three Pilgrimages; Leo Tolstoy (1828-1910), the great Russian writer; John. Galsworthy (1867-1933), an English novelist and playwright, the Nobel Prize laureate; Harold B. Wright (1872-1944), a pastor at the Christian Church and an American novelist; Erich M. Remarque (1898-1970), a German novelist, creator of a new genre of war veterans writing; Elizabeth Bowen (1899-1973), an IrishBritish novelist and short story writer; Daphne du Maurier (1907-1989), an English author and playwright; William Golding (1911-1993), a British novelist, playwright, and poet, the Nobel Prize winner. Virginia Woolf (1882-1941), of the most important modernist writers of the $20^{\text {th }}$ century; Katherine Mansfield (18881923), a prominent modernist writer. Also, important sources were the Bible and Qur'an.

\section{'Tree' Archetypes and its Patterns}

Tree

The Tree is a natural object that was translated into an archetype by mythology, pagan religion and lore in the early days of human civilization because people have always felt a strong affinity with and dependence on it. A source of shelter and food, the tree symbolism informed cults existing in many countries. In cosmogony of many primitive peoples, mystic powers were assigned to trees which were reflected in their metaphoric descriptions: Cosmic Tree, World Tree, World Axis, Tree of life, Tree of Wisdom, Tree of Knowledge, Wish-fulfilling tree, trees as abodes of spirits and saints, etc. Summing up the significance of the tree culture, Juan Cirlot, a Spanish poet, art critic, mythologist and compiler of a most comprehensive dictionary of symbols, wrote: "In its most general sense the symbolism of the tree denotes the life of the cosmos, its consistence, growth, proliferation, generative and regenerative processes. ... The tree becomes a symbol of absolute reality, that is of the center of the world" (Cirlot 1971, p. 347).

Certain trees were revered as sacred (the oak was sacramental to the Celts; the ash sacrosanct to the Scandinavian peoples; the sycamore to Egyptians). In Greek mythology, the highest gods Zeus and his wife Hera were known as the oak god and goddess. Laurel tree was the symbol of Apollo, who wore a laurel wreath, and 
the Olive tree was the symbol of Athena.

Researchers consider that the association of god/goddess with a certain tree may be purely accidental, arising from a very ancient connexion of the worship of the tree and the worship of a deity. For example, the cults of Aphrodite and the apple-tree might have been practiced in the same locality, and a contiguity was established in the course of time, a sacred character being ascribed to the tree as an emblem of Aphrodite (Foster 1899, p. 55).

The arbour culture of Ancient Egypt was rather complicated and geographically split. The sycamore was one of the most important trees, but there were also the persea, the date palm and the acacia related to different locations. The word 'sycamore' also had the meaning 'refuge' which developed the sense 'dwellings of gods.' "Hail thou Sycamore of the eastern sky who protects the god and on whose branches the gods are" (Buhl 1947, p. 88). Another sacred tree was the acacia, a tree in which life and death were contained (Buhl 1947, p. 86). Goddesses played a great part in the tree cult. Sycamore was identified with Nut or Hathor: "Hail thou sycamore of Nut, give to me of the water and of the air which are in thee" (Buhl 1947, p. 91). Goddesses were often depicted standing among the branches of the tree (sycamore or date palm) with feet hidden in the trunk laden with fruit and covered with thick foliage.

The relationship between Man and Nature is characterized by anthropomorphism- humanization of non-human objects. Fanciful thinking created dryads (tree nymphs or tree spirits) who lived inside trees and could take the form of beautiful young women. Dryads could arouse life energy even within dead wood. The most famous myth about dryads is that of Eurydice, an oak dryad, and Orpheus, a legendary poet and musician, who, when his wife died bitten by a venomous snake, descended to the Underworld and tried to bring her back to the light, but violated the admonition, looked back, and his wife remained forever in the Underground realm.

Early religious writings also endowed trees with human features and behavior. "When Christ's fate was known, in the forest the trees held council and resolved not to lend their wood for the execution. Every tree that the ax-men tried to cut, splintered and broke, or dulled the tool with knots" (Skinner 1911, p. 193). Throughout the Bible, saints and true believers are referred to as trees. "Blessed is the man who walks not in the counsel of the wicked... He is like a tree planted by streams of water, which yields its fruit in season and whose leaf does not witherwhatever they do prospers" (NIV 1984, Psalm 1, p. 383).

Trees may be turned into people and people into trees as Ovid described in his Metamorphoses and Antonio del Pollaiuolo (1429-1498), an Italian painter and sculptor represented in his oil-on-panel painting, created between 1470 and 1480 (Figure 1). The beautiful naiad Daphne is chased by Apollo and, as she implores to be spared, her father, a river god, turns her into a Laurel tree:

Scarce had she finish'd, when her feet she found

Benumb'd with cold, and fasten'd to the ground:

A filmy rind about her body grows;

Her hair to leaves, her arms extend to boughs:

The nymph is all into a laurel gone (Ovid 1826, p. 21). 
Figure 1. Antonio del Pollaiuolo. Apollo and Daphne

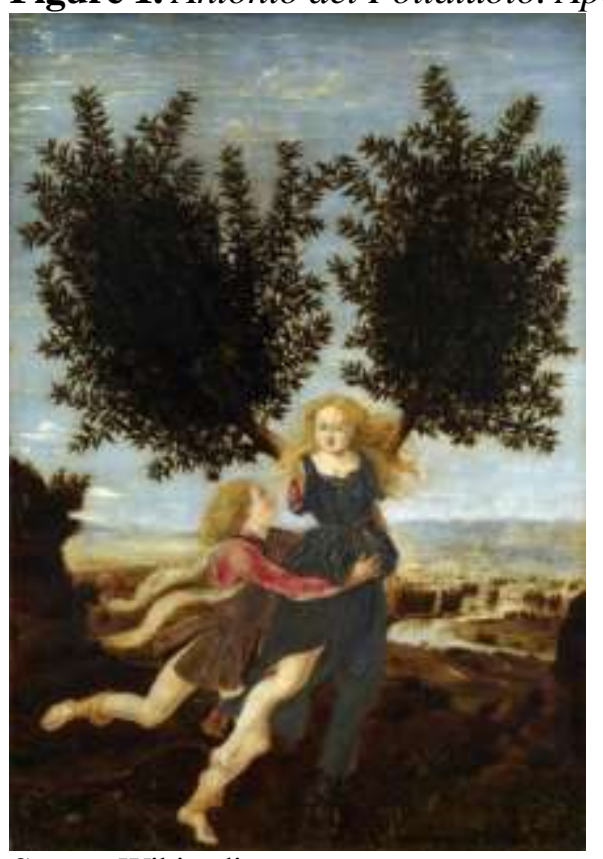

Source: Wikipedia.

Cassirer sees the ultimate roots of this myth in the depth of unrecorded time. The word Daphne signifying 'laurel' in Greek can be traced back to a Sanskrit ahana meaning 'the redness of dawn', thus the content of the myth becomes Apollo, the Sun god, is pursuing his bride, the dawn, who takes refuge in the bosom of her mother, the earth. An interesting turn in the interpretation of the myth based on word meanings and etymology! This is how Cassirer interprets the myth. "The story is a description of what one may observe every day: first, the appearance of the dawn light in the eastern sky, then the rising of the sun-god who hastens after his bride, then the gradual fading of the red dawn at the touch of the fiery rays" (Cassirer 1946, p. 4).

Trees are believed to be the 'progenitors of human race'. In Norse mythology, the great tree destroyed the old gods (Odin, Thor, Freyr, Loki) and the old world, but out of the trunk of the tree a man and a woman appeared, the seeds a new race. The Ancient Greeks thought that at the beginning of time cloud-ash was produced spawning small 'melia', which came together and created men of the Bronze Age. Meliae became nymphs of the ash tree and before women were created men married the nymphs and from them all of mankind was descended (MacPherson 2015).

In the Middle ages, in the genre-setting work The Pilgrimage of the Life of Man by Guillaume de Deguileville (1295-1358), we find a rare symbolic representation of the Tree as a wheel of Fortune (Figure 2), which, however, did not take root in the prospective literature, so we can classify it as an 'episodic' meaning; nevertheless, it should not be overlooked by researches as it is illustrative of how archetypal content is enriched in the hit or miss process. The Pilgrimage is unique in many aspects: though it is expressly a religious writing, an 
explication of the Christian doctrine, it contains multiple allusions to the Greek mythology not characteristic of such literature.

Figure 2. The Tree of Fortune

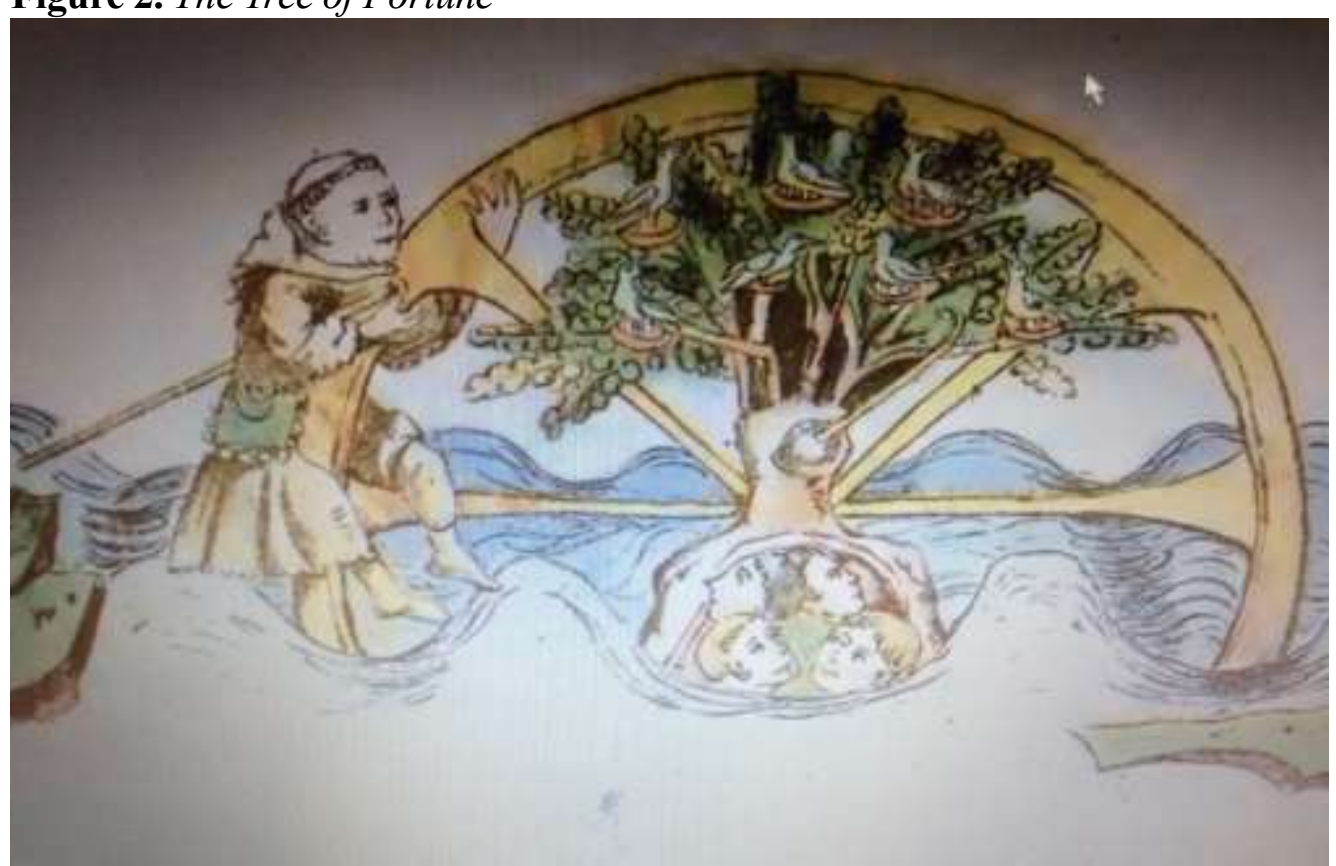

Source: Guillaume de Deguileville. The Pilgrimage of Man.

In the narrative, the pilgrim travels to Jerusalem and on his way encounters many dangers, baits, personalities who happen to be deadly sins, and strange things. At the end of his journey, trying to swim across a tempestuous sea, he sees a large tree; when he approaches it, he finds himself upon a wheel, which he had not noticed before. This wheel turns with great force round the tree which is full of birds' nests placed on different branches. The tree is hollow and has a hole at the top, through which a hand with a hooked stick appears from time to time to push some nests down. At the foot, there is another hole and in it are many people, who extend their hands thriving to climb up. By the tree he meets a double-colored (half-black, half-white) woman whose name is Fortune, who explains to him that the nests on branches represent the great fortunes of kings, of princes, and of prelates whom Evil Fortune may drag down to be trampled on; Good Fortune may assist those who are below to mount. The wheel is one of the perils of the sea named after the Greek "Charybdis", which absorbs many by its whirl" (Deguileville 1859, p. 52). The whirling movement is tertium comparationis for the mythological sea whirlpool and a religious idea of punishment represented in Deguileville's story by a turning wheel.

The mythical worldview gradually developed into specifically religious consciousness. "The two are so interwoven that they can nowhere be definitely separated and set off from each other" (Cassirer 1955, p. 239). With the

\footnotetext{
${ }^{1}$ A sea monster in Greek mythology, which dwelt in the Strait of Messina. It was later conceptualized as a whirlpool.
} 
development of the leading religions, the religious deification of nature ensued. The richness of tree symbolism was absorbed by religion, especially Christianity. Parallelisms with myths are striking, however, religious tree symbolism is a system per se. The functions of life and knowledge are divided between two different paradisiacal trees. In the Garden of Eden, God planted The Tree of Life and the Tree of The Knowledge of Good and Evil (NIV 1984, Genesis 2:9, p. 2).The tree of life does not give immortality to man: he must eat constantly "of the tree of life, and live forever" (ibid., Genesis 3:22, p. 3). The mythological vision of the tree as a pillar supporting heaven is transferred to Christianity as the Cross of redemption, a new axis of the world based on true faith. The relationship between the Cross and the Tree of Life forms a unity between life and death: "the life and death connotations of the tree symbol, which in primitive myth had been mere polarities, are unified anagogically through Christ's Cross, the true Lignum Vitae $^{2}$,which is also seen as a cosmic cross, as a new world-supporting and unifying tree" (Ladner 1979, p. 238). In religious symbolism, the transgression of God' s law by the first people had made the Tree of Life bare and dry, however it was made green again by the Cross (Ladner 1979, p. 237). In Christian iconography, the canonical Tree of Life is always in bloom, the Tree of Knowledge is dry (Cirlot1971, p. 349).

\section{Tree and Water Landscape}

Most frequently, the Tree archetype is combined with another primordial archetype - Water. The combination of the two life-giving natural objects produced a complex 'Landscape' archetype informed with diverse meanings. .

The associative power of imagination tied the notion of the 'center of the world' with 'a source of all life' in the oldest archetypal pattern of a 'tree and a stream of water' running from or below its roots. The analysis of myths of the primeval periods and early religious writings of peoples living geographically far apart that excludes any cultural exchanges exposes remarkable points of similarity. The oldest myths make reference to a mysterious tree at the center of the world and a nearby stream of water which divides into four rivers flowing into the four cardinal directions (Haynes 2009). It is repeated almost word for word in the Bible: "And a river watering the garden flowed from Eden; and from thence it was separated into four headwaters" (NIV 1984, Genesis 2:10, p. 2). Mythological representations of an ordinary landscape are transformed into a religious configuration of Eden.

The juxtaposition of "the two elements of the original creation" (Frye 1982, p. 137) forms a pattern which acquires new significative and aesthetic values observed in ancient and modern religious and literary writings. Thus, the Egyptian sacred tree stands on a sort of aquarium, symbolical of the Nile. From the upper part of the tree the goddess Nepte/Nephthys, a river goddess and the protector of the dead, pours streams of life-giving water from a vase (Warwick 1890, p. 5). In Scandinavian mythology, the three great roots of the world tree Yggdrasill

\footnotetext{
${ }^{2}$ Tree of life (Lat.)
} 
"descend into the underworld realm of gods where they gather every day by the sacred spring of Fate, the Well of Urd, to resolve disputes. At the base of the tree is the Spring of Mirmir (Remembrance), three goddesses of Fate water the roots of the great tree night and day and on the cosmic shuttle weave the fates of men and the world" (Cook 1974, p. 12). The underground landscape is poetized in Edda.

An ash I know, | Yggdrasil its name,

With water white $\mid$ is the great tree wet;

Thence come the dews $\mid$ that fall in the dales,

Green by Urth's well |does it ever grow (Bellows 2004, Völuspá, p. 9).

The mythological pattern was translated into a religious image of Paradise combining the Tree of Life (a symbol of revival and rebirth) and a stream of clear water cleansing wickedness and sins emblematic of true faith which is carried to all parts of the world. Frye called this landscape "the oasis imagery of trees and water" (Frye 1982, p. 142). The Bible begins and ends with the description of the river and the tree: "Then the angel showed me a river of the water of life, as clear as crystal, flowing from the throne of God and of the Lamb, down the middle of the great street of the city. On each side of the river stood the tree of life, bearing twelve crops of fruit, yielding its fruit every month. And the leaves of the tree are for the healing of the nations" (NIV 1984, Revelation 22: 12, p. 879).

In the apocryphal Gospel of Pseudo-Matthew, we also find a scene, in which the tree is complemented by a stream of water. Baby Jesus asks a palm tree to give his mother some fruit. He also asks God to "open from the roots a vein of water which has been hid in the earth, and immediately, here began to come forth a spring of water exceedingly clear and cool and sparkling" (Schaff 1886, p. 622). The same scene is depicted in The Qur'an: Mary was in labors when the babe Jesus or Gabriel cried to her from below her, saying: 'Grieve not: your Lord has provided a water stream under you. And shake the trunk of the date-palm towards you, it will let fall fresh ripe dates upon you, so eat and drink and be glad!" (The Qur'an 2015, surah 19, verses 24-26, p. 344).

\section{Archetypal Patterns in Literature}

\section{The Oasis Imagery of Trees and Water}

As the textual and contextual evidence of the literary pieces analyzed suggests, the use of the pattern 'Tree and Water' forms a mythical-religious framework for narrative figuration, which may vary among literary works by different authors displaying a particular subjectivity in providing highly nuanced representations. It immerses the reader into emotional and psychological worlds of characters. Erich Maria Remarque introduces the apparition of "poplars by a stream' in his anti-war novel All Quiet on the Western Front as an oasis amid the horror and the terror of war, shelling and gas attacks, squalor and hunger, blood and death, a phantom, a most cherished memory of Paul Baumer (the narrator) about his childhood in the pre-war time. The vision from the peaceful past acquires 
almost Biblical significance of Paradise unattainable in war time and condemns war.

\begin{abstract}
"Between the meadows behind our town there stands a line of old poplars by a stream. They were visible from a great distance, and although they grew on one bank only, we called them the poplar avenue. ... We sat beneath them on the bank of the stream and let our feet hang in the bright, swift waters. The pure fragrance of the water and the melody of the wind in the poplars held our fancies. We loved them dearly, and the image of those days still makes my heart pause in its beating" (Remarque 1975, p. 120).
\end{abstract}

Harold Wright, once a top-selling American author, in Their Yesterdays gives a different dimension to the archetype informing it with the meaning of fall and redemption, to be expected from the author with a professional theological education and experience. A little brook surrounded by greenery is a recurring image throughout the narrative with a plentitude of meanings: sweet reminiscences of the childhood, ingenuousness and chasteness, moral fall and rebirth, purification etc.

The characters of the novel used to play by the brook when they were innocent little children:

"It was only a little brook, but beautifully clear and fresh, for it had come only a short distance from its birth place in a glen under the hill. In some places, the long meadow grass almost touched above, making a cool, green, cradle arch through which the pure waters flowed with soft whispers. In other stretches, the green willows bent far over to dip their long, slim, fingers in the slow current that crept so lazily through the flickering light and shade that it seemed scarce to move at all" (Wright 1912, p. 133).

The introductory description of the brook is a metaphorical extension of the Biblical river of life and is evocative of Psalm 23, "He [the Lord - N.D.] makes me lie down in green pastures, he leads me beside quiet waters, he refreshes my soul" (NIV 1984, Psalm 23, p. 392). Life was harsh on both of them, they went through hardships, squalor, despair, and the author describes it in the following allegorical manner:

"The little brook was a safe stream for the boy and the girl to play beside. Nor did they know, then, that their streamlet flowed on and on until it joined the river; and that the river, in its course, led it past great cities that poured into it the poisons and the filth of their sewers, fouling its bright waters, until it was unfit for children to play beside" (Wright 1912, p. 135).

In the end, the Man and the Woman meet again by the brook and reunite now forever.

"It was in the afternoon and they were together down by the little brook, in the shade of the willows, where the stream, running lazily under the patches of light and shade, murmured drowsily seeming more than half asleep" (Wright 1912, p. 304). 
The analysis of these three excerpts reveals a U-shaped narrative structure typical of religious and homiletic writings. The first one being a real landscape outside a small town, evokes paradisiacal scenery of peace and harmony; the second one allegorically describes descent into a life of sin and ordeals using the image of polluted water; the last one implicates return to pristine chastity, redemption, and ascent to absolution.

\section{Four Apple Trees}

Archetypal patterns are an operant force for plot construction and development. In English literature there are four well-known stories of the same title - The Apple Tree: one by John Galsworthy, another by Daphne du Maurier, still another by Elizabeth Bowen, and the other by Katherine Mansfield - all based on different archetypal patterns.

Of all kinds of trees, the Apple tree received special significance both in mythology and religion. There are two famous apple trees: the tree bearing golden apples in the Garden of Hesperides (Hera's garden) and the Forbidden Fruit from the Garden of Eden - Christian tradition holds that it was an apple tree, which got the name of the Tree of Knowledge of Good and Evil. As a result, the apple tree acquired a special status and took on symbolic significance forming a rich paradigm of meanings: beauty, love, knowledge, temptation, transgression, death, etc. All in all, Foster described forty four facets of meaning (Foster 1899).

\section{The Tree of Aphrodite}

The Apple Tree by Galsworthy is a love story: a tragic love on the part of Megan, a simple, pretty country girl, and a fleeting "rush of passion" on the part of Ashurst, a university graduate. The setting for their love is "The pool, formed by the damming of a rock, and the big apple tree," nearby (Galsworthy 1918, p. 195). The tree was "nearly twice the height and size of any other, and leaning out towards the open meadow and the stream" (Galsworthy 1918, p. 220). Nature was in blossom when their love was conceived: "apple blossoms covering the orchard as with a rose and white quilt" (Galsworthy 1918, p. 213).

The story is based on two opposing planes: one of a mythopoeic perception of the surrounding world, in which there is no distinction "between the world of dream and the world of objective reality" (Cassirer 1955, p. 36); the other is the real world of logical thinking and rationalism, in which the self is distinct from the perceived environment. The two topoi meet and clash at crossroads by "a suicide's grave" of a girl Ashurst knew and was infatuated with a quarter of a century ago. Megan seemed to Ashurst "the living unearthly beauty of the apple blossom" (Galsworthy 1918, p. 224). But when he left the village, everything - even Megan - became unreal. "Had he really made love to her-really promised to take her away to live with him? He must have been bewitched by the spring, the night, the apple blossom!" (Galsworthy 1918, p. 241). He never came back, and Megan drowned herself in the shallow pool close to the big apple tree, in which it was impossible to be drowned as the ancient poet articulated it, "to lose the Love and 
the Pain forever" (Euripides 1902, p. 40); it was June then, but she had found a sprig of apple-blossom left over somewhere, and stuck it in her hair (Galsworthy 1918, p. 256).

The story is saturated with imagery creating a highly emotional reading. A conceptual focus of the narrative is the Apple Tree, the tree of Aphrodite emblematizing not only beauty and love but also discord and death (Littlewood 1968). The tree belongs both to the imaginary and real worlds and evokes symbolic resonance with Grecian myths and poetry. The meetings under the Apple tree take place in the nebulous light of the Moon. This nebulosity is emphasized by Ashurst's imagination and his infatuation with Grecian mythology. He constructed an imaginary world around himself relying on ancient Greek symbols. The orchard looks to him like the garden of the Hesperides surrounded by Assyrianlooking masses of the rocks. "In such a spot as this, fauns and dryads surely lived; nymphs, white as the crab-apple blossom, retired within those trees; fauns, brown as the dead bracken, with pointed ears, lay in wait for them" (Galsworthy 1918, p. 219) "All was unearthly here, fit for no earthly lovers; fit only for god and goddess, faun and nymph not for him and this little country girl" (Galsworthy 1918, p. 221) "And sometimes spring will come alive, and, like a mysterious Presence stand, encircling lovers with its arms, laying on them the fingers of enchantment" (Galsworthy 1918, p. 222). To him, Megan was all simple Nature and beauty, as much a part of this spring night as was the living apple blossom.

Water is an ever present element in the story marking landmark events in the plot development. It starts with the pool of clear water with a sandy bottom where Ashurst bathed on his arrival, the scene alluding to baptism by water, a spiritual bath for a person to be cleansed of all superficial and be brought back to his natural self; the pool that turned into the water of death for Megan. Besides, other sources of water are mentioned: little streams which were "very bright and full of burbling and whispering in spring" (Galsworthy 1918, p. 220); a pool in the cave at the edge of which he saw Stella (his future wife) and was infatuated by her looks; the sea water in whose depth Ashurst's friend was nearly drowned.

The most potent symbolic image arousing many associative links and echoes is the Apple tree sung by Euripides in Hippolytus and used by Galsworthy as a device providing coherence and comprehension for the narration. The story bookends with the line from Euripides: "The Apple-tree, the singing and the gold." The line refers to the Garden of the Hesperides (Daughters of Sunset), which marked the utmost limit to which man might travel; beyond it there is nothingness.

Yea, beyond that Pillar of the End

That Atlas guardeth, would I wend

Where a voice of living waters never ceaseth

In God's quiet garden by the sea (Euripides 1902, p. 39).

In Euripides' tragedy the line is pronounced by a chorus as Phaedra, a Cretan princess and the wife of Theseus, is about to kill herself after being rejected by her stepson Hippolytus with whom she has fallen in love. Parallelism is obvious: forgotten by Ashurst, Megan reached her limit. Caught in "a noose of death," she carries out her desperate plan. 
Ashurst's guilty conscience is seeking justification and finds it in the numinous: the vengeful goddess of Love is simply taking her toll. The motif of impossibility to escape from tragic love is emphatically pronounced in Hippolytus:

All life that is wild and young

In mountain and wave and stream,

All that of earth is sprung,

Or breathes in the red sunbeam

Yea, and Mankind. O'er all a royal throne,

Cyprian, Cyprian, is thine alone! (Euripides 1902, p. 66).

This wishful thinking has nothing to do with reality with which Ashurst cannot come to grips; the famous words reveal the harsh truth of the ruined life and love lost. "All his life he felt that there was something wanting, he longed for something he knew not what, there was always a hankering, and sense of waste" (Galsworthy 1918, p. 188). The final resolution of this tension comes via the symbol of the garden with the apple tree: the mythical garden of Hesperides turns into paradisiacal Eden lost for Ashurst. "There could be no garden of his choosing, of 'the Apple-tree, the singing, and the gold,' no achievable Elysium in life, or lasting haven of happiness. ... And a sudden ache beset his heart; he had stumbled on just one of those past moments in his life, whose beauty and rapture he had failed to arrest, whose wings had fluttered away into the unknown; he had stumbled on a buried memory, a wild sweet time, swiftly choked and ended" (Galsworthy 1918, pp. 189-190). He understood what was lacking in his life sincerity, emotional bond, and true love.

The writer creates his fictional world by blending the real world and natural environment with metaphorically represented, long gone world of Greek myths existing now at the level of symbols and archetypes, revived by the author, who makes skillful use of the archetypal pattern and establishes intertextual links with the ancient poem where the apple tree is one of the motives.

\section{Tree as Abode of Souls}

Quite a different pattern with a touch of the supernatural underlies and directs the plot of The Apple Tree by Daphne du Maurier. It draws on old beliefs that human souls can transmigrate after death into trees. At the beginning of the story, one morning, three months after his wife's death, the main character Buzz sees a tree which has always been there and unconsciously connects the old, crooked apple tree with his late wife Midge; in the shape of the tree he sees Midge's usual posture. "It was a trick of the light perhaps. ... the likeness was unmistakable. That martyred bent position, the stooping top, the weary branches, the few withered leaves like wispy hair; all of it protested soundlessly to the owner of the garden" (du Maurier 2004, p. 114). There is a young tree growing to the right of the old one, standing straight and firm, the lithe young branches lifted to the sky; in his imagination, this tree is associated with a farm girl he once kissed, whose skin felt "like a very young apple" (du Maurier 2004, p. 122). He projects the images of his 
wife and the farm girl onto the trees and hates the old one, wants to cut it down in order make space for the young tree.

Strange metamorphoses begin to happen to the old tree. Having been barren for years and "more than half dead," the tree begins to sprout buds and then bursts into rich blossom as if somebody had breathed new life into it. Later the tree bears fruit. Never in his life has Buzz seen a tree so laden with fruit. However, Buzz is disgusted at the sight of the tree in flower and the tree thickly hung with apples. "There was something monstrous in the sight, something distasteful; yet it was pitiful too that the months had brought this agony upon the tree, for agony it was, there could be no other word for it. The tree was tortured by fruit, groaning under the weight of it, and the frightful part about it was that not one of the fruit was eatable. Every apple was rotten through and through. Filthy tasting things. Stringy, beastly..." (du Maurier 2004, p. 144).The sight, the smell, the taste make Buzz sick. The flowers look pallid and sickly white; the smell of burning apple logs seems "sickly rancid" (du Maurier 2004, p. 128); the taste of apple jam nauseates him.

He is obsessed with the idea of destroying the tree; finally, at the beginning of winter, he cuts the tree down and gets rid of it. "Now the young one stood alone, above the steps, dwarfed no longer; and with her branches spread, glistening white, she belonged to the spirit world, a world of fantasy and ghosts. He wanted to stand beside the little tree and touch the branches, to make certain she was still alive, that the snow had not harmed her, so that in the spring she would blossom once again" (du Maurier 2004, p. 158). It looks pitiful and testifies to mental disorder because the country girl had been long dead, killed in a road accident. On the way to the young tree, he falls and his foot is trapped in the split stump of the old apple-tree. '"Let me go,' he shouted, 'let me go', as though the thing that held him there in its mercy had the power to release him" (du Maurier 2004, p. 159). There is nobody to help him, and sinking deeper, ever deeper into the snow, he feels as if "a hand, hesitant and timid, was feeling its way towards him in the darkness" (du Maurier 2004, p. 159).

In this story, the fantasy of the apple tree as abode of spirits or human souls is used by the author to describe the liminal state of the protagonist. With each description of Buzz' perception of the tree, we feel that he is plunging in insanity. Psychological state of guilt of which he is probably not aware pushes him into a psychic distress which ends up in his death.

\section{Tree as the Cross}

Most prominently the arborous theme in its relation to death on the Cross, redemption of sin and repentance is represented in Elizabeth Bowen's story, in which the old apple tree in the school garden turns into the tree of death and accursedness. For it is written in the Scriptures, "Cursed is everyone who is hung on a tree" (NIV 1984, Galatians 3:13, p. 824). It is a metaphorical extension of The Apple Tree of the Garden of Eden to the Cross of Christ's Crucifixion and new Lignum Vitae. In Christianity, it is the most enigmatic archetypal pattern - the relationship between the Tree and the Cross and the mystery of the Cross as the 
Tree of life. Frye (1982) emphasizes the dual nature of the Cross as an instrument of death and salvation. It is believed that the cross put out young green sprouts during Chris's passion. The essence is that after Christ's death, a Tree of Redemption was conceived - the Cross. "The tree of Paradise is only a prefiguration of the cross and this cross is the center of the world. It towers from Golgotha to heaven, gathering the whole world together ... the ever-green tree of life" (Rahner 1971, p. 62).

This motif in numerous variations is present in medieval iconography, where Christ is often depicted crucified not on the cross but on a tree either dry or with exuberant foliage, sometimes on an "inverted tree" hanged upside down. This fact is confirmed in some versions, especially early ones, of the Bible. They speak about Jesus "whom they [Jews] did slay, having hanged upon a tree" (Young 1862, Acts $10: 39$, p. 2412). In Greek mythology, the apple tree is also connected with hanging. It is a story of Melus, as told by Servius ${ }^{3}$. He relates that Melus, priest of Aphrodite, and foster-father of Adonis, hanged himself on a tree at the latter's early death. Aphrodite then turned him into an apple-tree, which was named $\mu \eta \lambda i^{4}{ }^{4}$ (Foster 1899, p. 44).

Bowen tells a story of two orphan girls Myra and Doria, both about 10, not pretty, always getting into some kind of trouble, who are rejected by other girls, are despised and laughed at. They stick together, but their relationship cannot be called friendship, it is a kind of "dependence on one another" of two outcasts. In their isolation, the "only happy part" of their lives was "the games we played and the stories we told in a lonely part of the garden with one beautiful old apple tree. Nobody else ever came there" (Bowen 1989, p. 469). It was something of their own, something which made them feel happy and dignified. Later, Myra makes friends with a "very pretty and clever" girl who had a family and a home, and is accepted by other girls. For the sake of this new friendship and out of fear to become an outcast again, she betrays Doria, who is left all by herself. Doria takes it the hard way. Myra says, "She never wept; she used to walk about by herself. It was as though everything I got free of had fallen on her, too: she was left with my wretchedness" (Bowen 1989, p. 469). One day the girls go to the apple tree, and Myra says "terrible things to her. And wished she was dead" (Bowen 1989, p. 469). That night Doria hanged herself in the apple tree. Myra, who went looking for Doria, saw her feet just above her head. It was September - two or three apples fell down. After the traumatic experience, Myra got very ill: "I thought the leaves would choke me. Whenever I moved in bed, an apple fell down" (Bowen 1989, p. 469).

The tree was cut down, the place was filled with new turf as if there had never been an apple tree at all. But the tree remained with Myra, suppressed remorse taking the form of being haunted by the tree. "There is always the apple tree. Its roots are in me. It takes all my strength,” (Bowen 1989, p. 470) explains Myra,

\footnotetext{
${ }^{3}$ Maurus Servius Honoratus was a late fourth-century and early fifth-century grammarian, with the contemporary reputation of being the most learned man of his generation in Italy.

${ }^{4}$ The classical Greek word $\mu$ í $\lambda$ ov (mēlon), meant any fruit, but was borrowed into Latin in the meaning 'apple'. The similarity of this word to Latin mặlum meaning 'evil' may also have influenced the apple becoming interpreted as the 'forbidden fruit'.
} 
who is now married, lives in a comfortable, solid Victorian house and whose husband tries to rid her of this nightmare. The tree is driving Myra mad as if it were requital for sin. "If I stay here, the tree grows in the room. If I go out, I find it darker than all the others against the sky" (Bowen 1989, p. 470). The atmosphere imbued with horror is imparted on other characters. Lancelot, a guest of the house, hears "a thud-thud-thud - three times like apples falling" (Bowen 1989, p. 465). This idea of apples falling from the "leafy height" in the shut-up room reshapes "an innocent pastoral image" now seen black through a dark transparency (Bowen 1989, p. 465). Mrs. Bettersley, a sensible, no-nonsense lady, succumbed to the horrifying atmosphere, too. She admits, "It's impossible. One can't get past ... it's like an apple tree" (Bowen 1989, p. 466).

The cross as a symbol of death becomes a symbol of redemption. When Jesus was crucified, he took upon himself the curse for humanity's wrongdoing. In the story, Doria becomes a scapegoat, who took upon herself all injustice and the burden of rejection from which her friend was suffering. But this suicide proved too much for Myra: guilty conscience turned out to be a heavier burden than the childish fear of losing her acceptance by the school girls; for years, it was destroying her personality. The apple tree was exorcized and a new Myra emerged at Christmas; however, the author leaves the reader in the dark as to whether redeeming suffering brought about a resurgence of the ego.

William Golding uses this symbol in his famous novel The Spire (1964). Dean Jocelin obsessed with the idea of building a high spire on the tower of the Cathedral, sacrifices to his ambition people, his faith, his soul, his health and finally life. However, before he dies, the vision of the Spire is replaced by the image of the tree. While his soul is "flying through the panicshot darkness like a bluebird over water," he "leaves behind the words of magic and incomprehension —It's like the apple tree!" (Golding 1964, p. 215).

\section{Forbidden Fruit}

A very short story by $\mathrm{K}$. Mansfield also called the Apple Tree is based on the Biblical story of the forbidden tree in the Garden of Eden from which Adam and Eve ate an apple, but written with a touch of elegant irony and humor. The setting is a house looking out on two orchards. One, that the family called the "wild" orchard, lay beyond the vegetable garden, where for some reason, the boys never played. But the other orchard, lay far away and was hidden from the house. "One year the orchard had its Forbidden Tree. It was an apple-tree discovered by Father and a friend during an after-dinner prowl on Sunday afternoon." The friend assures the Father that the apple tree is rare, very rare. "Hardly ever see "em in England nowadays" (Mansfield 1915, p. 2). The father believes it and forbids anyone, even his two sons to touch the apples. Every Sunday the Father went there to admire his precious tree and watch the apples ripe. At last the day came when Father took his sons to the apple tree to taste the apples. The ceremony was very solemn: "Very slowly and very carefully he picked two apples growing on a bough. He laid one apple down, opened the pearl-pen knife and neatly and beautifully cut the other in half" (Mansfield 1915, p. 3) all the while continuing to admire the apple. 
Together, the boys took a bite, their mouths were filled with a disgusting stuff - "a horrible taste of something dry." Not wanting to disappoint The Father, they lied that it was delicious. When the Father tasted his apple, he spat it out and never went near the apple-tree again.

The pattern underlying the story is easily recognizable: it is a story of Adam and Eve's fall and the apple as the symbol of their sin and transgression. There is comparison of the tree from the boys' garden to the tree of Eden: "The apple-tree like the Virgin Mary ${ }^{5}$ - seemed to have been miraculously warned of its high honor, standing apart from its fellows, bending a little under its rich clusters, fluttering its polished leaves, important and exquisite before Father's eye" (Mansfield 1915, p. 2). Other characters from the paradisiacal garden are recognizable, too. The friend acts as the Serpent tempting the Father to think that the unnamed apple is very rare and marvelous. The words ring so sweet to him his purchase is worth more than he paid for it. He immediately acts like God forbidding his children to touch the apples. K. Mansfield follows the Biblical story up to minute details. The scene of the boys tasting the fruit resembles that of Adam nearly choking on the forbidden fruit which stuck in his throat. However, the story has an unexpected twist at the end. The boys are obedient and do not touch the apples, but their reward is the disgusting taste of the fruit. The Father is disappointed, too: no promised benefits from being the owner of a rare tree. Things are not what they look.

\section{Green Tree-Dry Tree Pattern}

Religious worldview generated one more archetypal pattern "the Green Tree - the Dry Tree," which is embodied both in religious mythos and literary works. The symbol of the Dry tree is related to Jesus' crucifixion or the Tree of Knowledge, which became dry on the day of Christ's crucifixion. In poetry, the famous lines by Goethe turned this antithesis into proverbial wisdom: "Grau, teurer Freund, ist alle Theorie/Und grim des Lebens goldner Baum." [All theory is gray, my friend, But forever green is the tree of life] (Goethe 1973, p. 509).

The pattern of 'Dry Tree' stimulated the iconography of an Early Netherlandish artist Peter Christus' painting Madonna of the Dry Tree (about 1465) (Figure 3). The Virgin and the Child are set against the black background on a dead tree trunk within a dried crown of thorns, a unique visualization of the motif. The only source of radiance is the Virgin's face and the Child emanating light, complemented by small sparks of the letter ' $\mathrm{A}$ ' among the dead branches meaning 'Ave'. The dry tree is supposed to be the Tree of Knowledge. It was also believed that the Virgin brought the tree back to life. Here is how it is described by Guillaume de Deguileville. The pilgrim and his guiding angel see souls playing with an apple between two trees, one green and one dry. The angel explains that the souls are playing with the apple that grew on the green tree, which is the Virgin, and the apple is Christ; the apple was transferred to the barren tree to restore it to life for mankind's salvation. The verdant tree complains that the apple is taken from her,

\footnotetext{
${ }^{5}$ The apple tree is considered to be the Virgin Mary's tree.
} 
but the dry tree explains that only Christ can pay the price of redemption and be the Savior (Baert 2004).

Figure 3. Peter Christus (1410-1475) Madonna of the Dry Tree

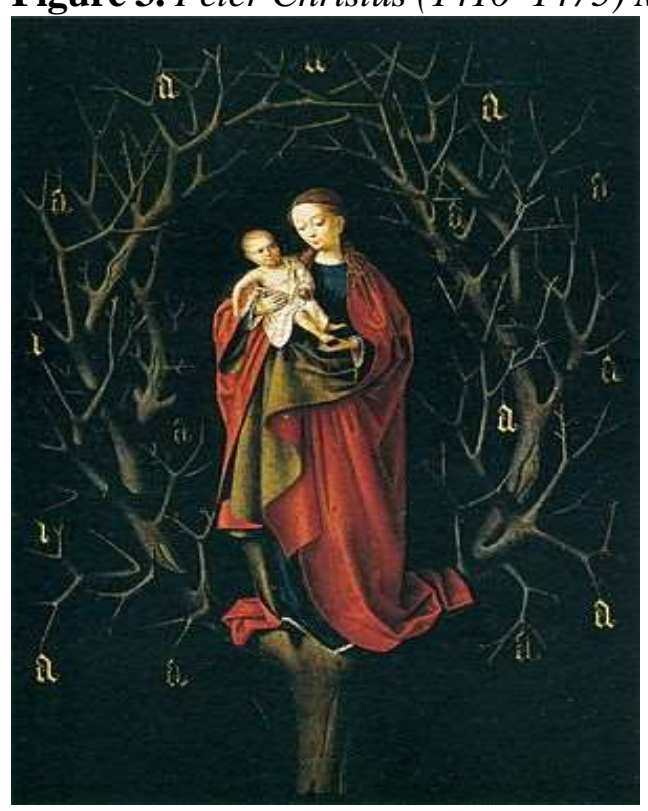

Source: Pinterest.ru.

Christ's crucifixion turned many leafy trees into bare ones. Mandeville ${ }^{6}$ describes the Mount of Mambre, on which an oak grew from whom grief sapped all life and made it dry. "And there is a tree of Oke, the which men clepen the Dry Tree. And theyesaye that it hath ben this sithe the beginnynge of the World; and was sumtymegrene and bare Leves unto the Tyme that Oure Lord dyede on the Cross; and thanne it dryede; and so dydenalle the Trees that werenthanne in the World. " [And there is an Oak tree, which people call the Dry Tree. And they say that it has been there since the beginning of the World; and was at one time green and bore leaves up to the time that Our Lord died on the Cross; and then it dried; and so did all the trees that were there in the World] (Mandeville 2002, p. 25).

The pattern 'Dry Tree - Green Tree' is instantiated in several forms. One motif is related to magic transmutations through the grace of God. A dry tree may be brought back to life as a sign that a sinner has received absolution from his past sins. In Canterville Ghost, Oscar Wilde uses this archetypal pattern as a token of God's forgiveness of the sinner who has suffered martyrdom and for whose soul an innocent virgin has prayed. The "old withered almond-tree has blossomed" and its flowers were seen in the moonlight. "God has forgiven him," said Virginia gravely, as she rose to her feet, and a beautiful light seemed to illumine her face" (Wilde 2007, p. 209).

Another motif is related to the natural cycle of the tree life: autumnal death winter sleep - spring awakening and summer flourish. This archetypal pattern is

\footnotetext{
${ }^{6}$ Sir John Mandeville is the supposed author of a collection of travelers' tales from around the world, first circulated between 1357 and 1371.
} 
used by Leo Tolstoy in War and Peace to show Prince Andrew's spiritual renascence and re-emergence from the past pain, desolation, and emotional withdrawal. The two descriptions are in tune with the character's emotional states. The first one is of the old oak tree which has not yet come into leaf.

"At the edge of the road stood an oak. It was an enormous tree. With its huge ungainly limbs sprawling unsymmetrically, and its gnarled hands and fingers, it stood an aged, stern, and scornful monster among the smiling birch trees. ...and this oak, refused to yield to the charm of spring or notice either the spring or the sunshine.

"Spring, love, happiness!" this oak seemed to say. "Are you not weary of that stupid, meaningless, constantly repeated fraud?...There is no spring, no sun, no happiness!... so I stand, and I do not believe in your hopes and your lies" (Tolstoy 1952, p. 235).

A few days later Prince Andrew was going through the same forest and did not recognize the oak.

"The old oak, quite transfigured, spreading out a canopy of sappy dark-green foliage, stood rapt and slightly trembling in the rays of the evening sun. Neither gnarled fingers nor old scars nor old doubts and sorrows were any of them in evidence now. Through the hard century-old bark, even where there were no twigs, leaves had sprouted such as one could hardly believe the old veteran could have produced.

"Yes, it is the same oak," thought Prince Andrew, and all at once he was seized by an unreasoning springtime feeling of joy and renewal. All the best moments of his life suddenly rose to his memory" (Tolstoy 1952, p. 236).

It is of interest to note that Virginia Woolf uses the same archetypal pattern in her phantasmagoric novel Orlando. The situation is similar to that described by Leo Tolstoy. At the age of thirty (Prince Andrew was thirty one) Orlando was going through the worst crisis in his life. A rejected lover and ridiculed poet, he retreated to his mansion, lead a life of a recluse and sought consolation in the oak tree that grew on top of the mountain "whence on fine days half of England with a slice of Wales and Scotland thrown in could be seen" (Woolf 2003, p. 47). He came to the oak tree every day to find peace with himself and protection from the world.

“... he flung himself under his favorite oak tree and felt ... he might make out what years remained to him in tolerable content. Here he came then, day after day, week after week, month after month, year after year. He saw how the oak tree had put forth its leaves and shaken them to the ground a dozen times in the process" (Woolf 2003, p. 47).

The fact that writers as different as L. Tolstoy and V. Woolf chose the same archetypal pattern and even the same species of tree in their construction of similar situations serves as a proof of universality intuitively felt by writers belonging to different cultures and age. 


\section{Conclusion}

Organic archetypal patterns based on cognitive awareness of ecological surroundings establish a relation of literary imagery to the natural world as a specific way of representation of themes, motifs, characters' emotions, and plots and illustrate the role of imagination in creating meaning.

The roots of organic archetypes go back to the primordial, pre-conceptual period when all abstractions were to be reified by the human mind. In contact with the environment the naive consciousness gave prominence to certain phenomena and imbued them with meaningful content. The perception of the ambient world was selective - not all properties of an outer object were impressed upon the human mind, but only those which appeared relevant at the moment and suited the process of representing abstract ideas as tangible things or living beings (e.g., an apple symbolized sin and transgression and also Jesus Christ).

Initially, a limited number of features were picked out, but with the passing of time, new facets were added. The consequent transformations of an archetype via particular extensions involved the perception of the environment as influenced by the state of knowledge, changing forms of consciousness, contemporary ideologies, religion, etc., that is successive cultural paradigms in which patterns were reinterpreted and overlaid with new meanings. Thus, the famous Greek myth about Apollo and Daphne is a "remake" of an older myth about the Sun and his bride Dawn.

Epistemologically, organic archetypes are a product of the cognizing mind which at the mythical stage of human development invented a special kind of representation of accumulated knowledge in the form of mythical and later religious patterns. By establishing permanent connections between a natural object and mental spaces (topoi), it prepared a platform of future logical concepts and transition from mythico-religious to rational thinking. However, the old intuitive patterns did not disappear; instead, they remained in phylogenetic memory of humankind as vestiges of our ancestral history (phylogenesis), were translated into a system of cultural codes within which archetypes developed a pattern-setting capacity amply used by writers of different epochs and genres.

To become an archetype, a pattern must acquire a certain degree of universality. Episodic representations, no matter how picturesque they may be, are filtered out by the "collective unconscious". Due to this universality and inter textual connections, patterns still carry a strong sense-bearing potential and are capable of triggering emotional responses in the reader. Imaginative use of archetypal patterns helps writers create fictional lifeworlds including settings, situations, events, emotional state of characters, etc. and also employ them as a plot-constructive force underlying the surface structure of a literary text. As we tried to show in the article, the same archetype (the apple tree) produces four different scenarios for narratives exteriorizing its different facets (the forbidden fruit, abode of souls, or the tree of redemption).

Archetypal patterns are complex cultural phenomena deeply embedded in our cultural memory involving in its sphere literature, myth, religion and - art. The knowledge, at least partial, of archetypal patterns determines better comprehension and adequate interpretation of literary works. 


\section{References}

Baert B (2004) A heritage of holy wood: the legend of the true cross in text and image. Translated by L Preedy. Leiden/Boston: Brill.

Bellows HA (2004) The poetic Edda: the mythological poems. Mineola, New York: Dover Publications Inc.

Bodkin M (1934) Archetypal patterns in poetry: psychological studies of imagination. New York: Vintage.

Bourdieu P (1984) Distinction: a social critique of the judgment of taste. Translated by R Nice. Cambridge, Mass.: Harvard University Press.

Bowen E (1989) The apple tree in collected stories. New York: The Ecco Press.

Brown C, Toadvine T (Eds.) (2003) Eco-phenomenology: back to the earth itself. Albany: State University of New York Press.

Buhl M (1947) The goddesses of the Egyptian tree cult. Journal of Near Eastern Studies 6(2): 80-97.

Cassirer E (1946) Language and Myth. Translated by S Langer. New York: Dover.

Cassirer E (1955) Philosophy of symbolic forms. Volume 2: Mythical Thought. Translated by R Manheim. New Haven: Yale University Press.

Cirlot J (1971) A dictionary of symbols. $2{ }^{\text {nd }}$ Edition. London: Routledge.

Cook R (1974) The tree of life. Symbol of the center. London: Thames and Hudson.

Deguileville G (1859) A modern prose translation of the ancient poem entitled the pylgrymage of man. London: Basil Montagu Pickering.

du Maurier D (2004) The apple tree. In The Birds \& Other Stories, 114-159. London: Virago Press.

Euripides (1902) Hippolytus. Translated into English rhyming verse by G Murray. London: G. Allen.

Foster B (1899) Notes on the symbolism of the apple in classical antiquity. Harvard Studies in Classical Philology 10: 39-55. Department of the Classics, Harvard University.

Frazer JG (1890) The golden bough. New York: Macmillan.

Frye N (1957) Anatomy of criticism. Princeton, New Jersey: Princeton University Press.

Frye N (1982) The great code: the bible and literature. New York: Harcourt Brace Jovanovich.

Galsworthy J (1918) Five tales. London: W. Heinemann.

Goethe J W (1973) Werke (Works). Volume 12. Munich: C.H. Beck.

Goethe J W (2009) The metamorphosis of plants. Cambridge, Mas.: The MIT Press.

Golding W (1964) The spire. New York: Harcourt, Brace \&World, Inc.

Haynes G (2009) Tree of life, mythical archetype: revelations from the symbols of ancient Troy. San Francisco: Symbolon.

Jung C (1964) Man and his symbols. New York: Anchor Press book.

Kant I (1998) Critique of pure reason. Edited by P Guyer, A Wood. Cambridge: Cambridge University Press.

Ladner G (1979) Medieval and modern understanding of symbolism: a comparison. Speculum 54(2): 223-256.

Larson J (2004) The theory of archetypes. New York: Nova Science Publishers, Inc.

Littlewood A (1968). The symbolism of the apple in Greek and Roman literature. Harvard Studies in Classical Philology 72: 147-181.

Locke J (1965) An essay concerning human understanding. London: Dent.

MacPherson D (2015) Tree spirituality: an introduction to trees, humans, and the realm they share. New York: Babybook.

Mandeville J (2002) The defective version of Mandeville's travels. In S Michael (ed.), 
Early English Text Society, volume 319. Original Series. Oxford: Oxford University Press.

Mansfield K (1915) The apple tree. Retrieved from: www.goodreads.com. [Accessed 20 June 2020]

Mukhopadhyay D (2014) The neuro-philosophy of archetype in aesthetics: from Plato to Zeki and beyond. PsyArt 18 (Dec): 340-369.

Neumann E (1995) The origins and history of consciousness. Princeton N.Y.: Princeton University Press.

New International Version of the Holy Bible - NIV (1984). Colorado Springs: International Bible Society.

Ovid (1826) Metamorphoses. Edited by S Garth.Translated by J Dryden. London: J.F. Dove.

Rahner H (1971) Greek myths and Christian mystery. New York: Biblo \& Tannen.

Remarque EM (1975) All quiet on the western front. New York: Fawcett Books.

Schaff P (1886) Ante-Nicene Fathers. Volume 8. Edinburgh: Grand Rapids, Christian Classics Ethereal Library.

Skinner C (1911) Myths and legends of flowers, trees, fruits, and plants in all ages and in all climes. Philadelphia \& London: J. B. Lippincott Company.

The Qur'an (2015) Translated by H Abdel. New York: Oxford University Press Inc.

Tolstoy L (1952) War and peace. Chicago/London/Toronto: William Benton.

Warwick T (1890) Cultus Arborum. Privately Printed.

Wilde O (2007) The Canterville Ghost. In Collected Works. London: Wordsworth Library Collection.

Woolf V (2003) Orlando: a biography. London UK: Wordsworth Classics.

Wright H (1912) Their yesterdays. New York: A. L. Burt Company.

Young R (1862) The holy bible, consisting of the old and new covenants; Translated according to the Letter and Idioms of the Original Languages. London: British and Foreign Bible Society. 